\title{
Aerodynamic Analysis of Onshore Commercial Large Scale Wind Turbine
}

\author{
Akın ILHAN ${ }^{1}$ ORCID 0000-0003-3590-5291 \\ Mehmet BILGILI'2 ORCID 0000-0003-5339-6120 \\ Melih SARI ${ }^{3}$ ORCID $0000-0003-4148-2926$ \\ Beşir ŞAHIIN*3 ORCID 0000-0003-0671-0890
}

\author{
${ }^{1}$ Ankara Yildirim Beyazit University, Faculty of Engineering and Natural Sciences, Energy \\ Systems Engineering Department, Ankara \\ ${ }^{2}$ Cukurova University, Ceyhan Engineering Faculty, Mechanical Engineering Department, \\ Adana \\ ${ }^{3}$ Cukurova University, Engineering Faculty, Mechanical Engineering Department, Adana
}

Geliş tarihi: 26.07.2021 Kabul tarihi: 10.12.2021

Atıf şekli/ How to cite: ILHAN, A., BILLGILI, M., SARI, M., ŞAHİN, B., (2021). Aerodynamic Analysis of Onshore Commercial Large Scale Wind Turbine. Çukurova Üniversitesi, Mühendislik Fakültesi Dergisi, 36(4), 965-977.

\begin{abstract}
In this study, the variations of yearly aerodynamic characteristics of horizontal axis wind turbines operating in an installed wind power plant (WPP) in detail was revealed by means of the blade element momentum theory and angular momentum theory. For this aim, five identical wind turbines of the three-bladed type having rated power of $2 \mathrm{MW}$ located in an installed wind farm in Hatay province of Turkey were selected. According to the results obtained from horizontal axis wind turbines having rated power of $P_{r}=2 \mathrm{MW}$, annual average turbine mechanical power output $(P)$, power coefficient $\left(C_{P}\right)$, free-stream wind speed $\left(U_{\infty}\right)$, and turbine rotor rotational speed $(\Omega)$ were obtained as $672.68 \mathrm{~kW}, 30.80 \%, 8.49 \mathrm{~m} / \mathrm{s}$ and $12.81 \mathrm{rpm}$, respectively. Moreover, annual average axial flow induction factor $(a)$, thrust coefficient $\left(C_{T}\right)$, thrust force $(T)$ and blade tip speed ratio $(\lambda)$ were calculated as $0.10,0.34,75.18 \mathrm{kN}$ and 6.57 , respectively.
\end{abstract}

Keywords: Aerodynamic characteristics, Blade element momentum theories, Energy analysis

\section{Kara Tipi Ticari Büyük Ölçekli Rüzgâr Türbininin Aerodinamik Analizi}

\section{$\ddot{\mathbf{O z}}$}

$\mathrm{Bu}$ çalışmada, kurulu bir rüzgâr santralinde (RES) çalışan yatay eksenli rüzgâr türbinlerinin yıllık aerodinamik özelliklerinin değişimleri kanat elemanı momentum teorisi ve açısal momentum teorisi yardımıyla detaylı olarak ortaya konmuştur. Bu amaçla, Türkiye'nin Hatay ilinde kurulu bir rüzgâr çiftliğinde yer alan, anma gücü $2 \mathrm{MW}$ olan üç kanatlı tipte beş özdeş rüzgâr türbini seçilmiştir. Yatay 
eksenli rüzgar türbinlerinden elde edilen sonuçlara göre; anma gücü $P_{r}=2 \mathrm{MW}$, ylllık ortalama türbin mekanik güç çıkışı $(P)$, güç katsayısı $\left(C_{P}\right)$, serbest-akım rüzgar hızı $\left(U_{\infty}\right)$ ve türbin rotor dönüş hızı $(\Omega)$ değerleri, sırasıyla, $672,68 \mathrm{~kW}, \% 30,80,8,49 \mathrm{~m} / \mathrm{s}$ ve $12,81 \mathrm{rpm}$ olarak elde edilmiştir. Ayrıca, yıllık ortalama eksenel akış indüksiyon faktörü $(a)$, itme katsayısı $\left(C_{T}\right)$, itme kuvveti $(T)$ ve kanat ucu hız oranı ( $\lambda$ ) değerleri, sırasıyla, $0,10,0,34,75,18 \mathrm{kN}$ ve 6,57 olarak hesaplanmıştır.

Anahtar Kelimeler: Aerodinamik karakteristikler, Kanat elemanı momentum teorisi, Enerji analizi

\section{INTRODUCTION}

Energy is one of the most essential and indispensable requirements of the present World. Besides, energy unquestionably has a necessary item in terms of the technological developments of countries, economic progress, and, most importantly, withal in human life [1-2]. In recent years, global energy demand which is developing in parallel with the developing technology, population growth, and rapid depletion of fossil fuels, has demonstrated a significant increase [3-6]. The increase in energy consumption is especially based on some factors such as population growth, the continuous improvement of the living standards, and the industrialization of the developing countries. By reaching the year 2030, a $21 \%$ increase in the total energy demand is unfortunately expected. Also nowadays, issues such as climate change-related concerns, alternative energy production sources, greenhouse gas emissions and reducing of the environmental other negative impacts related to fossil fuels, have become the most critical problems of the whole governments, and in order to tackle these urgent problems directly which occur recently, such topics are evaluated within the scope of the leading responsibilities of the World states.

The fact that energy generation, today, is not very economical, the utilization of energy causing negative environmental factors, and steadily increasing energy demand of mankind have effectuated some troubles in the sustainable energy demand. Current demand for energy, when evaluated in terms of a broad perspective such as economic, environmental, climate and human needs, it unfortunately becomes unsustainable. On the other hand, in order to provide that $\mathrm{CO}_{2}$ emissions which occur during energy production remain within the specified limits, prominence should be given primarily to renewable energy sources [7-8].

There is a functional relationship between wind speed and power output considering the power generation which is caused by the interaction that occurred between the wind and the wind turbine, and it is quite essential to handle wind turbine aerodynamic parameters within this scope. The forces that the wind acts on the rotor cause periodic and fluctuating aerodynamic forces on the rotor. These effects demonstrate an increase by means of turbulence and dynamic influences [9]. Within this scope, the specifications belonging to the aerodynamic performance of the wind turbines in a considered region are required to be well understood. In the evaluation of aerodynamic performances of wind turbines, sufficient knowledge for average wind conditions, wind turbulence and wind events, is needed. For a considered region, within the scope of appropriate wind turbine selection or its design, a detailed evaluation of this information is essential. Besides, within the scope of the declaration of the energy efficiency of wind energy systems and their price effectiveness, performance analysis is required. In the context of providing proper level management of wind turbines, obtaining their control and operations, examining of optimum wind speed and turbine aerodynamic characteristics are relatively important. Accordingly, aerodynamic characteristics belonging to the wind turbine are pretty influential on the issues such as in the evaluation of the turbine performance, in the determination of preventive maintenance and operating factors and on the optimizations of these factors, in the constitution of cut-in and cut-out functions, in the best supply of turbine management 
and administration, in the acquisition of the best provision of the wind turbine propulsion, in the forecastings belonging to power generation, and as well in the determinations of system life [10-13].

Many studies are found in the literature regarding the aerodynamic parameters of wind turbines [1423 ]. But, there is a limited number of related studies considering the performance and aerodynamic characteristics of commercial large-scale wind turbines. Among them, Ilhan et al. [24] examined the aerodynamic characteristics of 2 MW capacity commercial large scale wind turbine. In this study, they considered the measured data of an onshore operating wind farm in Turkey. They conducted the tip-speed ratio as 7.12 in the most productive wind turbines. Besides, the maximum power coefficient at the tip-speed ratio was reported to be $30 \%$. On the other hand, Bilgili and Yasar [25] performed a study of efficiency analysis of a 2 MW horizontal axis wind turbine operating in an onshore wind farm in Turkey. In this study, they reported the maximum power coefficient as $30 \%$, maximum thrust force as $140 \mathrm{kN}$, and optimum tip-speed ratio as 7 . Furthermore, Cooney et al. [26] exhibited a performance analysis on $850 \mathrm{~kW}$ of a commercial large-scale wind turbine located in Ireland. Also in this study, they proposed the conducted results can be handled in the assessment of the future wind farms projects in terms of economy and technical feasibility. Sedaghat and Mirhosseini [27] studied the aerodynamic investigation of a $300 \mathrm{~kW}$ commercial wind turbine installed in Semnan province. Wind turbine characteristics including power coefficient, thrust coefficient, angle of attack, drag and lift coefficients, angle of the relative wind, axial and angular induction factors were calculated in their study by the method of blade element momentum theory. Taner [28] performed an economic analysis of a wind power plant located in the Cappadocia region of Turkey. The escalation method of inflation was considered in this study. Besides, it was determined that a 3 MW wind power plant can be constructed in this region. The results also indicated that due to the high-energy wind potential of this region, the construction of an energy plant in this region could be economical.
In this study, by utilizing the blade element momentum and angular momentum theories, the aerodynamic characteristics of the horizontal axis wind turbines located in an installed farm in Turkey were investigated in detail. For this aim, the energy analysis was performed in the examinations of the turbine characteristic curves belonging to the various aerodynamic parameters of operating wind turbines in this existing wind farm. In the calculation of wind turbine aerodynamic characteristics, data belonging to the hub-height wind speed $\left(U_{D}\right)$, atmospheric air temperature $\left(T_{a t m}\right)$, wind turbine mechanical output power $(P)$, and turbine rotor rotational speed $(\Omega)$ were used. In this regard, the aerodynamic parameters were exposed corresponding to the free-stream wind speed $\left(U_{\infty}\right)$ values and these obtained real model curves were compared with respect to the manufacturer characteristic values which were determined by the manufacturer company.

\section{MATERIALS AND METHODS}

Simple momentum theory was applied in determining the aerodynamic characteristics of horizontal axis wind turbines. Figure 1 shows the energy interaction in the flow tube with the rotating rotor, or in other words, with the disk in the wind. As can be seen, the output power generated by the wind turbine depends on the interaction between the rotor and wind. In a continuous flow system, if the principle of conservation of mass is applied, Equations 1-2.

$\dot{\mathrm{m}}_{\mathrm{in}}=\dot{\mathrm{m}}=\dot{\mathrm{m}}_{\text {out }}$

$\rho \mathrm{A}_{\text {in }} \mathrm{U}_{\infty}=\rho \mathrm{A}_{\text {rotor }} \mathrm{U}_{\text {rotor }}=\rho \mathrm{A}_{\mathrm{w}} \mathrm{U}_{\mathrm{w}}$

the equations above are obtained. Here, $\rho$ is the air density, $A$ is the cross-sectional area, and $U$ is the speed of the wind. Also, symbols in and $\infty$, rotor, and $w$ are used as subscripts to indicate the inlet area of the stream tube at far upstream and the freestream wind speed, the cross-sectional area of the rotor disc and hub-height wind speed, and exit area of the stream tube at far wake and the wind speed at far wake or also referred as dead zone wind speed, respectively. If the momentum conservation theory is applied in the flow tube as follows, equations 
demonstrated above are obtained. If the Bernoulli equation is applied between upstream and downstream cross-sections with the assumption that the rotating disc in near-surface upstream and nearsurface downstream wind velocities are equal, in this case, the following equations are obtained [9] (Equations 3-7).

$\Delta \mathrm{M}=\mathrm{T}$

$$
\begin{aligned}
& \Delta \mathrm{M}=\rho \mathrm{A}_{\text {in }} \mathrm{U}_{\infty}^{2}-\rho \mathrm{A}_{\mathrm{w}} \mathrm{U}_{\mathrm{w}}^{2} \\
& \mathrm{~T}=\rho \mathrm{A}_{\text {rotor }} \mathrm{U}_{\text {rotor }}\left(\mathrm{U}_{\infty}-\mathrm{U}_{\mathrm{w}}\right) \\
& \mathrm{P}_{\mathrm{atm}}+\frac{1}{2} \rho \mathrm{U}_{\infty}^{2}=\mathrm{P}_{\mathrm{iu}}+\frac{1}{2} \rho \mathrm{U}_{\text {rotor }}^{2} \\
& \mathrm{P}_{\mathrm{atm}}+\frac{1}{2} \rho \mathrm{U}_{\mathrm{w}}^{2}=\mathrm{P}_{\text {id }}+\frac{1}{2} \rho \mathrm{U}_{\text {rotor }}^{2}
\end{aligned}
$$

When Equations (6) and (7) are combined, the pressure drop across the rotor blade plane inlet and outlet is obtained as follows:

$\left(\mathrm{P}_{\mathrm{iu}}-\mathrm{P}_{\mathrm{id}}\right)=\frac{1}{2} \rho\left(\mathrm{U}_{\infty}^{2}-\mathrm{U}_{\mathrm{w}}^{2}\right)$

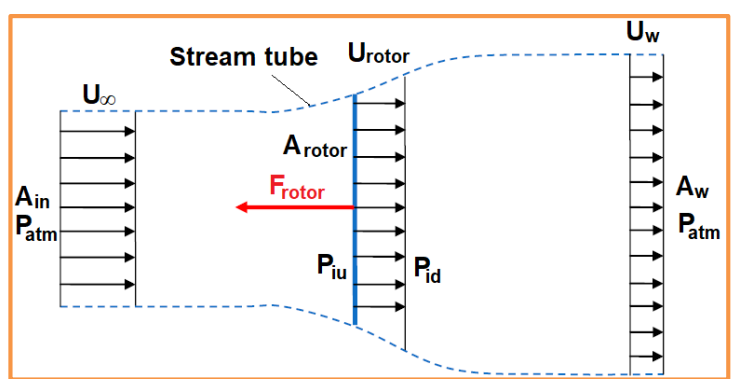

Figure 1. Energy interaction of the rotating disc inside the air flow tube

This difference in pressure obtained in Equation (8) will result in a pushing force on the rotor blade plane.

$\mathrm{T}=\left(\mathrm{P}_{\text {iu }}-\mathrm{P}_{\mathrm{id}}\right) \mathrm{A}_{\text {rotor }}=\frac{1}{2} \rho \mathrm{A}_{\text {rotor }}\left(\mathrm{U}_{\infty}^{2}-\mathrm{U}_{\mathrm{w}}^{2}\right)$

Taking together with Equations (5) and (9) for thrust forces, the expression of hub-height wind speed, $U_{\text {rotor }}$ depending on free-stream wind speed $\left(U_{\infty}\right)$ and the wind speed at the far wake $\left(U_{w}\right)$ is obtained as follows, (Equations 10-11)
$\mathrm{U}_{\text {rotor }}\left(\mathrm{U}_{\infty}-\mathrm{U}_{\mathrm{w}}\right)=\frac{1}{2}\left(\mathrm{U}_{\infty}^{2}-\mathrm{U}_{\mathrm{w}}^{2}\right)$

$\mathrm{U}_{\text {rotor }}=\frac{1}{2}\left(\mathrm{U}_{\infty}+\mathrm{U}_{\mathrm{w}}\right)$

The axial flow induction factor $(a)$ is expressed as follows, depending on the hub-height wind speed $\left(U_{D}\right)$ and the free-stream wind speed $\left(U_{\infty}\right)$, (Equation 12)

$\mathrm{a}=1-\frac{\mathrm{U}_{\text {rotor }}}{\mathrm{U}_{\infty}}$

Knowing the free-stream wind speed $\left(U_{\infty}\right) ; U_{\text {rotor }}$, and $U_{w}$ velocities are obtained in terms of axial flow induction factor $(a)$ by the following equations [9] (Equations 13-14):

$\mathrm{U}_{\text {rotor }}=\mathrm{U}_{\mathrm{D}}=\mathrm{U}_{\infty}(1-\mathrm{a})$

$\mathrm{U}_{\mathrm{w}}=\mathrm{U}_{\infty}(1-2 \mathrm{a})$

Besides, rotor shaft power $(P)$ obtained by the turbine due to the thrust force $(T)$ and the airflow can be calculated by the following equations (Equations 15-16):

$\mathrm{T}=2 \rho \mathrm{A}_{\text {rotor }} \mathrm{U}_{\infty}^{2} \mathrm{a}(1-\mathrm{a})$

$\mathrm{P}=2 \rho \mathrm{A}_{\text {rotor }} \mathrm{U}_{\infty}^{3} \mathrm{a}(1-\mathrm{a})^{2}$

The power coefficient $\left(C_{p}\right)$, which expresses the efficiency of the wind turbine, is given by Equations (7) and (8), respectively, depending on the freestream wind speed $\left(U_{\infty}\right)$ or only on the axial flow induction factor $(a)$, (Equations 17-18)

$\mathrm{C}_{\mathrm{p}}=\frac{\mathrm{P}}{\frac{1}{2} \rho \mathrm{U}_{\infty}^{3} \mathrm{~A}_{\text {rotor }}}$

$\mathrm{C}_{\mathrm{p}}=4 \mathrm{a}(1-\mathrm{a})^{2}$

The maximum value of the power coefficient is determined by calculating the value of the axial flow induction factor, $a=1 / 3$ using Equation (19) which is substituted at Equation (18) subsequently to expose the value of the Betz limit demonstrated in Equation (20) as follows, 
$\frac{d C_{p}}{d a}=4(1-a)(1-3 a)=0$

$\mathrm{C}_{\text {pmax }}=16 / 27=0.593$

This value is known as the Betz limit and represents the maximum efficiency that can be obtained from a wind turbine. On the other hand, the thrust coefficient $\left(C_{T}\right)$ to be applied to the disc (rotor blade) can be expressed by the following equations [9] (Equations 21-22),

$\mathrm{C}_{\mathrm{T}}=\frac{\mathrm{T}}{\frac{1}{2} \rho \mathrm{U}_{\infty}^{2} \mathrm{~A}_{\text {rotor }}}$

$\mathrm{C}_{\mathrm{T}}=4 \mathrm{a}(1-\mathrm{a})$

The differential torque origination on the rotor disc will be equal to the rate of change of the angular momentum of the air passing through the disc crosssection (Equation 23),

$\delta \mathrm{Q}=\rho \delta \mathrm{A}_{\text {rotor }} \mathrm{U}_{\infty}(1-\mathrm{a}) 2 \Omega \mathrm{a}^{\prime} \mathrm{r}^{2}$

Here, a' is the angular flow induction factor, $\Omega$ is the turbine rotor rotational speed, and $r$ is the radial radius of the rotor disc. The differential rotor shaft power $(\delta P)$, which forms on the rotor disc, can be expressed by Equation (24) depending on the differential of the term including torque origination on the rotor disc, $Q$ and turbine rotor rotational speed, $\Omega$ [9],

$\delta \mathrm{P}=\delta \mathrm{Q} \Omega$

$\mathrm{P}=\rho \delta \mathrm{A}_{\mathrm{d}} \mathrm{U}_{\infty}(1-\mathrm{a}) 2 \Omega^{2} \mathrm{a}^{\prime} \mathrm{r}^{2}$

By taking Equations (16)-(25) together, Equation (26) is structured as follows,

$\mathrm{U}_{\infty}^{2} \mathrm{a}(1-\mathrm{a})=\Omega^{2} \mathrm{a}^{\prime} \mathrm{r}^{2}$

At the end of the rotor disc, i.e., at the radius $r=R$, the following equation can calculate the blade tip speed ratio $(\lambda)$ (Equations 27),

$\lambda=\frac{\mathrm{R} \Omega}{\mathrm{U}_{\infty}}$

\section{RESULTS AND DISCUSSIONS}

In this study, data of horizontal axis wind turbines located in wind farms in the Hatay province of Turkey, was used [24]. The technical characteristics of equivalent wind turbines are shown in Table 1. The technical details of VESTAS V80-2.0MW type wind turbines include rotor diameter $\left(D_{\text {rotor }}\right) 80 \mathrm{~m}$, the rotor swept area $\left(A_{d}\right) 5,027 \mathrm{~m}^{2}$, tower height 67 $\mathrm{m}$, number of blades $(n) 3$, nominal turbine rotor rotational speed $(\Omega) 16.7 \mathrm{rpm}$ and turbine rated power $\left(P_{r}\right)$ of $2,000 \mathrm{~kW}$. The measured data for five different turbines $(T 1, T 2, T 3, T 4$, and $T 5)$ were taken for the considered year. The parameters measured from each discrete turbine are the data of the rotor blade plane including hub-height wind speed $\left(U_{D}\right)$, atmospheric air temperature $\left(T_{a t m}\right)$, turbine mechanical output power $(P)$, and turbine rotor rotational speed $(\Omega)$ on the rotor blade plane.

Table 1. The technical specifications of five identical wind turbines located in WPP

\begin{tabular}{|l|c|}
\hline \multicolumn{1}{|c|}{ Features of the wind turbines } & Feature \\
\hline Rotor diameter $\left(D_{\text {rotor }}\right)$ & $80 \mathrm{~m}$ \\
\hline Rotor swept area $\left(A_{d}\right)$ & $5.027 \mathrm{~m}^{2}$ \\
\hline $\begin{array}{l}\text { Nominal turbine rotor rotational } \\
\text { speed }\end{array}$ & $16.70 \mathrm{rpm}$ \\
\hline Rotor operating range & $9-19 \mathrm{rpm}$ \\
\hline Number of blades $(n)$ on the route & 3 \\
\hline $\begin{array}{l}\text { Hub height (tower height }) \\
\text { The wind speed at which the } \\
\text { turbine blades begin to turn (cut-in } \\
\text { wind speed) }\end{array}$ & $4 \mathrm{~m} / \mathrm{s}$ \\
\hline $\begin{array}{l}\text { The nominal wind speed of the } \\
\text { turbine }\end{array}$ & $15 \mathrm{~m} / \mathrm{s}$ \\
\hline $\begin{array}{l}\text { Turbine shutdown or cut-out wind } \\
\text { speed }\end{array}$ & $25 \mathrm{~m} / \mathrm{s}$ \\
\hline Turbine rated power $\left(P_{r}\right)$ & $2.000 \mathrm{~kW}$ \\
\hline $\begin{array}{l}\text { The working frequency and } \\
\text { voltage of the alternator }\end{array}$ & $50 \mathrm{~Hz}, 690 \mathrm{~V}$ \\
\hline
\end{tabular}

Firstly, the daily mean values of the data for the four aerodynamic parameters measured at intervals of 10 minutes were calculated, and the annual variations of parameters related to these obtained averages were exposed. Accordingly, based on the daily 
average values of the turbine mechanical output powers $(P)$ obtained from wind turbines having a maximum power capacity of $2,000 \mathrm{~kW}\left(P_{r}\right)$, it is observed that power values reaching this value are obtained in a minimal number of daily mean values. While the daily average turbine mechanical output power values obtained from the examined wind turbines, during the year, demonstrate a variation within a value range $P=0.00 \mathrm{~kW}$ and $P=1,991.75$ $\mathrm{kW}$, the annual mean wind turbine mechanical output power $(P)$ value obtained from all wind turbines was calculated as $P=672.68 \mathrm{~kW}$. On the other hand, while the daily mean hub-height wind speeds $\left(U_{D}\right)$ on the rotor blade plane demonstrated a variation in the value range between $U_{D}=0.56 \mathrm{~m} / \mathrm{s}$ and $U_{D}=17.68 \mathrm{~m} / \mathrm{s}$ during the year, the annual average hub-height wind speed $\left(U_{D}\right)$ was calculated to be $U_{D}=7.73 \mathrm{~m} / \mathrm{s}$. Besides, the annual variation of the daily average atmospheric air temperature $\left(T_{a t m}\right)$ values obtained from five turbines was also analyzed. In this regards, the daily mean atmospheric air temperature $\left(T_{a t m}\right)$, throughout the year, demonstrated a variation in the value range between $T_{a t m}=5.10^{\circ} \mathrm{C}$ and $T_{a t m}=31.27^{\circ} \mathrm{C}$, the annual average atmospheric air temperature $\left(T_{a t m}\right)$ was calculated to correspond $T_{a t m}=19.36{ }^{\circ} \mathrm{C}$. Although the variations in the atmospheric air temperature $\left(T_{\text {atm }}\right)$ do not immensely influence the turbine performance and the wind turbine mechanical output power $(P)$, atmospheric air temperature $\left(T_{a t m}\right)$ is one of the crucial parameters among turbine characteristics because the atmospheric air temperature $\left(T_{a t m}\right)$ causes the change of the density of the air passing through the turbine rotor blades as well as the mass flux.

The annual variations of the daily average wind turbine rotor rotational speed $(\Omega)$ values obtained from five different wind turbines were examined. While the daily mean wind turbine rotor rotational speed values present a variation within the range of $0.00 \mathrm{rpm} \leq \Omega \leq 16.70 \mathrm{rpm}$ during the year, the annual average wind turbine rotor rotational speed was calculated to be $\Omega=12.81 \mathrm{rpm}$. Additionally, it has also been identified that the investigated wind turbines operate at a nominal rotor rotational speed, of $\Omega=16.70 \mathrm{rpm}$, corresponding to a proportion of approximately $45 \%$ of the year-round.
The variation of the daily mean axial flow induction factors $(a)$ calculated for five wind turbines over the considered year was also investigated. When this situation is taken into account, it is seen that the daily average axial flow induction factor $(a)$ values including all turbines demonstrate a variation within the range of $0.00 \leq a \leq 0.27$ during the considered year, and the annual mean value of the axial flow induction factor $(a)$ of the wind turbines was calculated as $a=0.10$. On the other hand, the annual variation of the daily average turbine power coefficients $\left(C_{P}\right)$ was calculated for five wind turbines in the concept of the energy analysis. While the values belonging to the daily average turbine power coefficient $\left(C_{P}\right)$, demonstrates a variation within the range of $0.00 \leq C_{p} \leq 0.58$ throughout the considered year, the annual mean value of the turbine power coefficients $\left(C_{P}\right)$ was reported as $C_{P}=0.30$.

The annual variations of the daily mean thrust coefficient $\left(C_{T}\right)$, thrust force $(T)$, and blade tip speed ratio $(\lambda)$ values belonging to five wind turbines were studied based on the aerodynamic analyses. Based on the obtained results; the daily mean thrust coefficient $\left(C_{T}\right)$ values, throughout the year, demonstrated a variation with the range of $0.00 \leq C_{T} \leq 0.69$, the daily mean thrust force $(T)$ values have a variation within the range of 0.00 $\mathrm{kN} \leq T \leq 145.52 \mathrm{kN}$, and the daily mean blade tip speed ratio $(\lambda)$ values presented a variation within the range of $0.00 \leq \lambda \leq 9.89$. On the other hand, the annual mean values belonging to five wind turbines indicating at which daily value the related aerodynamic characteristics throughout the year correspond to, were calculated as $C_{T}=0.34, T=75.18$ $\mathrm{kN}$, and $\lambda=6.57$, respectively. As a result, the value ranges expressed according to the minimum and maximum values of the daily averages created over the considered year using all turbine aerodynamic characteristics obtained from five turbines and the annual mean values of these aerodynamic parameters are given in Table 2. To sum up, the daily averages created along the year through the utilization of all wind turbine aerodynamic characteristics obtained over five wind turbines coincide to which minimum and maximum values of the aerodynamic parameter value ranges and 
annual mean values of these aerodynamic parameters are given in this table.

The variations of the aerodynamic characteristics obtained from wind turbines of WPP with respect to the free-stream wind speed $\left(U_{\infty}\right)$ have also been studied. Initially, variations of the values belonging to the daily average wind turbine mechanical output power $(P)$ obtained from five wind turbines presented dependent on the free-stream wind speed $\left(U_{\infty}\right)$ are demonstrated in Figure 2. As the freestream wind speed reaches approximately $U_{\infty}=3$ $\mathrm{m} / \mathrm{s}$, it has been identified that wind turbines prominently started power generation and as well has been identified that this power generation withal increased in direct proportion with free-stream wind speed $\left(U_{\infty}\right)$. It has been observed that wind turbines started maximum power generation in case if freestream wind speed $\left(U_{\infty}\right)$ attained a nominal speed value of approximately $U_{\infty}=15 \mathrm{~m} / \mathrm{s}$ and as well has been observed that power generation remained approximately at a constant value exceeding this speed value. On the other hand, the measured values of the turbine mechanical output power $(P)$ obtained for the five wind turbines appear to be quite compatible with each other, but these measured values are reported to be smaller than the manufacturer characteristic values determined by the wind turbine manufacturing company. The manufacturer characteristic values are shown to be located along the manufacturer characteristic curve (MCC). Besides, the alterations of the daily average power coefficient $\left(C_{P}\right)$ values obtained from five wind turbines presented with respect to the freestream wind speed $\left(U_{\infty}\right)$ are exhibited in Figure 3. It is possible to divide the $C_{P}-U_{\infty}$ performance curve into three regions within the specific free-stream wind speed $\left(U_{\infty}\right)$ value ranges:

- Region 1: $3 \mathrm{~m} / \mathrm{s} \leq U_{\infty} \leq 5 \mathrm{~m} / \mathrm{s}$, region of low wind speeds,

- Region 2: $5 \mathrm{~m} / \mathrm{s} \leq U_{\infty} \leq 10 \mathrm{~m} / \mathrm{s}$, region of moderate wind speeds,

- Region 3: $10 \mathrm{~m} / \mathrm{s} \leq U_{\infty} \leq 25 \mathrm{~m} / \mathrm{s}$, region of high wind speeds.

The power coefficient $\left(C_{P}\right)$ values of wind turbines lessen in Region 1 having lower free-stream wind speed $\left(U_{\infty}\right)$ values and in Region 3 having higher free-stream wind speed $\left(U_{\infty}\right)$ values. For a given free-stream wind speed, $U_{\infty}$ value, rotor efficiency is a function of the rotor rotation rate. Efficiency decreases in the cases when the rotor rotates so slowly.

Table 2. Minimum, maximum, and annual average values of the turbine characteristics depending on their daily averages along the year

\begin{tabular}{|c|c|c|c|c|}
\hline Characteristic & Unit & Min. & Max. & Av. \\
\hline$T_{a t m}$ & ${ }^{\circ} \mathrm{C}$ & 5.10 & 31.27 & 19.36 \\
\hline$U_{\infty}$ & $\mathrm{m} / \mathrm{s}$ & 0.56 & 18.19 & 8.49 \\
\hline$U_{D}$ & $\mathrm{~m} / \mathrm{s}$ & 0.56 & 17.68 & 7.73 \\
\hline$U_{w}$ & $\mathrm{~m} / \mathrm{s}$ & 0.01 & 17.24 & 6.97 \\
\hline$\Omega$ & $\mathrm{rpm}$ & 0.00 & 16.70 & 12.81 \\
\hline$P$ & $\mathrm{~kW}$ & 0.00 & $1,991.75$ & 672.68 \\
\hline$a$ & - & 0.00 & 0.27 & 0.10 \\
\hline$C_{P}$ & - & 0.00 & 0.58 & 0.30 \\
\hline$C_{T}$ & - & 0.00 & 0.69 & 0.34 \\
\hline$T$ & $\mathrm{kN}$ & 0.00 & 145.52 & 75.18 \\
\hline$\lambda$ & - & 0.00 & 9.89 & 6.57 \\
\hline
\end{tabular}

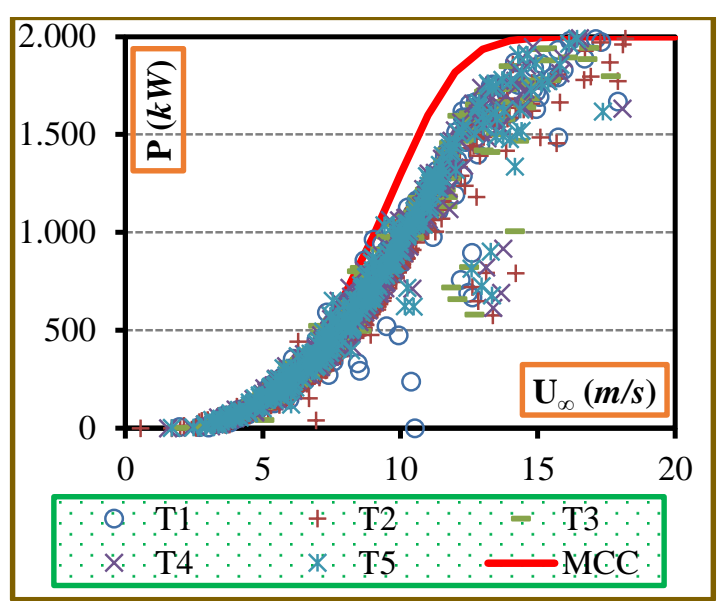

Figure 2. Variation of daily average wind turbine mechanical output power $(P)$ values depending on the free-stream wind speed $\left(U_{\infty}\right)$

For a considered wind speed value, the rotor efficiency is a function of wind turbine rotor rotational speed $(\Omega)$. In the case of the rotor to rotate so slowly, a significant decline in the efficiency originates, because in this case, the blades allow too much air to pass through the rotor disc without 
contacting with blades. For example, if a theoretical situation having the rotor rotating at very low rotational speeds, however as well having the wind approaching the rotor disc possessing quite high speeds is taken into account: If such case eventuates, depending to the circumstance of the blades to rotate at very low speeds, a certain amount of the air mass approaching the rotor can pass across the disc without interacting with the rotor and thus cannot transmit its energy to the blades. In the opposite, i.e., in case of the rotor to rotate so quickly, again, a drop in the efficiency occurs, because, in this case withal, inside the rotor-blade plane, the turbulence generated by one blade incrementally negatively influences the following blade. Namely, in a theoretical situation of the rotor rotating at very high rotational speeds, however in the same situation having wind approaching the rotor to be so tardy, deviations may occur in the flow pattern constituted as the wind beam passes over the wind turbine. On account of depending to the high rate of turbulence and also the vorticity generations, losses in the energy may eventuate. In either of these cases considered, the interaction actualized between the rotor and the wind flow cannot be in a sufficient quantity, and for this reason, enough efficiency cannot be provided. Consequently, in both of these cases withal, generations of lower values of power coefficients $\left(C_{P}\right)$ are occurred.

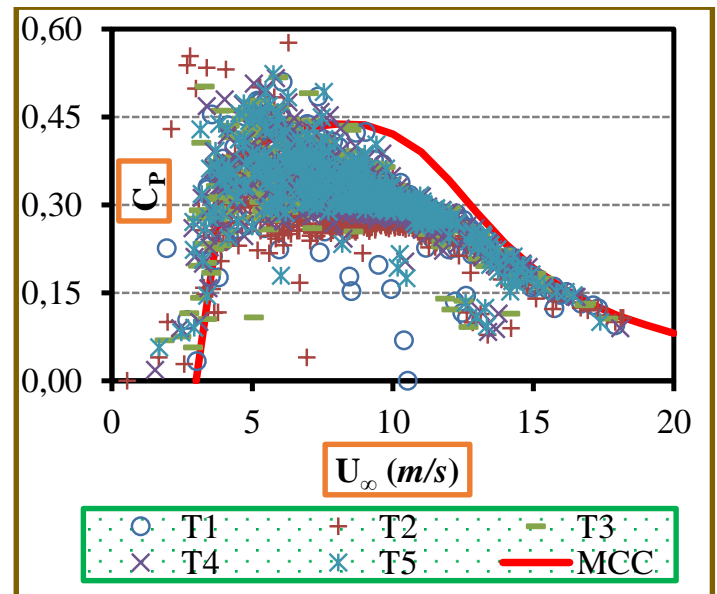

Figure 3. Change of daily mean turbine power coefficient $\left(C_{p}\right)$ values based on freestream wind speed $\left(U_{\infty}\right)$
On the other hand, at the Region 2, having moderate free-stream wind speed $\left(U_{\infty}\right)$ values, turbine power coefficients $\left(C_{p}\right)$ reached maximum values by exceeding $C_{p}=30 \%$. However, under the nominal free-stream wind speed value of $U_{\infty}=15 \mathrm{~m} / \mathrm{s}$ in which wind turbines actualize maximum turbine mechanical output power $(P)$, i.e., at the Region 3 involving high free-stream wind speed values, the turbine power coefficient $\left(C_{p}\right)$ values were calculated as approximately $C_{p}=18 \%$. Furthermore, the turbine power coefficient $\left(C_{p}\right)$ values calculated for five wind turbines were shown to be generally slightly lower than the manufacturer characteristic values determined by the turbine manufacturer.

Figures 4 and 5 respectively show the variations of daily average axial flow induction factor $(a)$ and thrust coefficient $\left(C_{T}\right)$ values presented with respect to the free-stream wind speed $\left(U_{\infty}\right)$. As in the case of the $C_{P}-U_{\infty}$ performance curve, it is possible to distinguish also 3 regions considering $a-U_{\infty}$ and $C_{T^{-}}$ $U_{\infty}$ performance curves. At the value range including the turbine power coefficient $\left(C_{P}\right)$ to be the highest and free-stream wind speed $\left(U_{\infty}\right)$ values to have $U_{\infty}=5 \mathrm{~m} / \mathrm{s}$ and $U_{\infty}=10 \mathrm{~m} / \mathrm{s}$ extreme values and defined as the $2^{\text {nd }}$ region, the mean axial flow induction factor $(a)$ and the average thrust coefficient $\left(C_{T}\right)$ values were found approximately to be $a=0.1$ and $C_{T}=0.4$, respectively. However, considering the $3^{\text {rd }}$ region under the nominal freestream wind speed of $U_{\infty}=15 \mathrm{~m} / \mathrm{s}$ where the turbine power is maximum, these cited values are calculated approximately as $a=0.05$ and $C_{T}=0.19$, respectively.

The variations of the daily average values of the total thrust force $(T)$ applied by the wind to the rotor depending on the free-stream wind speed $\left(U_{\infty}\right)$ for five wind turbines taken into account are shown in Figure 6. The actual thrust force $(T)$ values calculated for the wind turbines are generally lower than the values constituted by the manufacturer characteristic thrust force curve expressed in terms of the free-stream wind speed $\left(U_{\infty}\right)$ function. Furthermore, according to Eq. (15) belonging to thrust force $(T)$, and because of this force to be dependent to both " $U_{\infty}^{2}$ " as well as "a(1-a)" terms: A breaking point occurs at a definite free-stream wind speed $\left(U_{\infty}\right)$ value in the function curve of 
thrust force $(T)$ defined with respect to the free stream wind speed $\left(U_{\infty}\right)$. For example, according to the manufacturer characteristic thrust force $(T)$ values, at the $U_{\infty}=12.01 \mathrm{~m} / \mathrm{s}$ value of the free-stream wind speed $\left(U_{\infty}\right)$, the thrust force reaches its maximum value of $T=169.36 \mathrm{kN}$. On the other hand, for the considered $T 1, T 2, T 3, T 4$, and $T 5$ wind turbines, the values belonging to the measured actual thrust force reach the maximum values of $T=144.85 \mathrm{kN}, \quad T=141.50 \mathrm{kN}, T=146.52 \mathrm{kN}$, $T=145.96 \mathrm{kN}$, and $T=144.85 \mathrm{kN}$ at a corresponding free-stream wind speed of $U_{\infty}=12.31 \mathrm{~m} / \mathrm{s}, U_{\infty}=12.52$ $\mathrm{m} / \mathrm{s}, U_{\infty}=12.10 \mathrm{~m} / \mathrm{s}, U_{\infty}=12.96 \mathrm{~m} / \mathrm{s}$, and $U_{\infty}=13.23$ $\mathrm{m} / \mathrm{s}$, respectively.

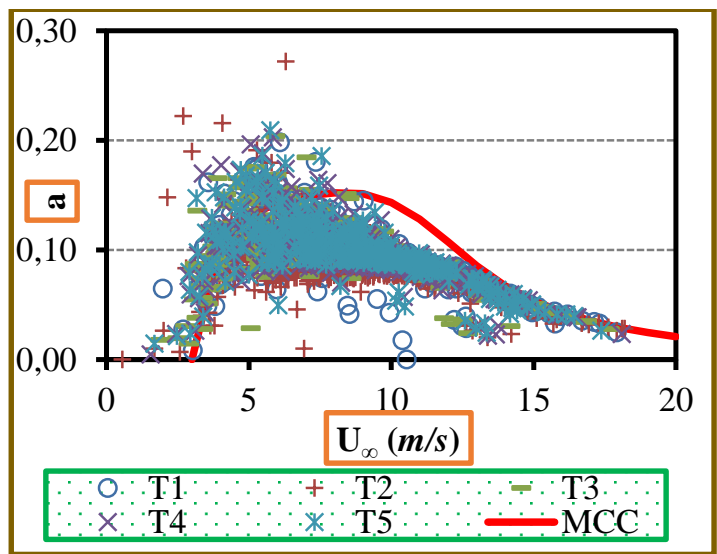

Figure 4. Alteration of daily mean axial flow induction factor $(a)$ values with respect to the free-stream wind speed $\left(U_{\infty}\right)$

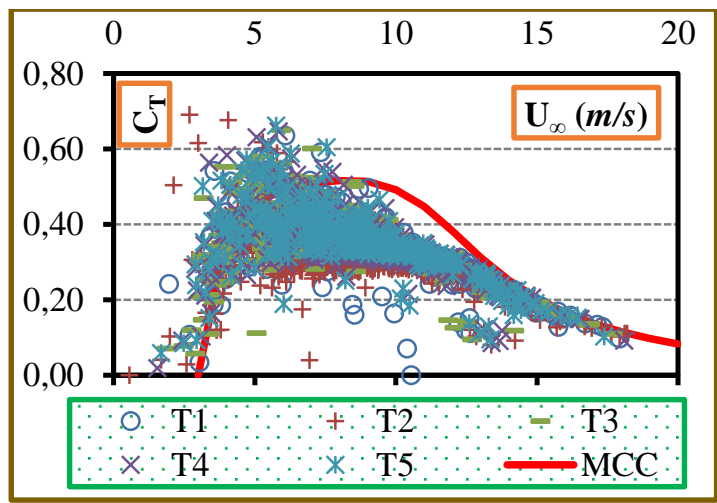

Figure 5. Variation in daily mean thrust coefficient $\left(C_{T}\right)$ values with free-stream wind speed $\left(U_{\infty}\right)$

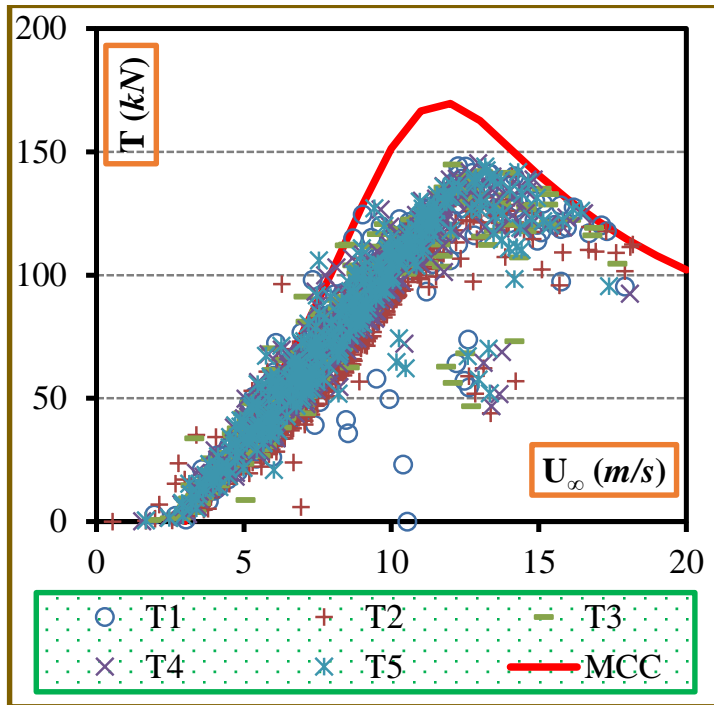

Figure 6. Change in daily mean thrust force $(T)$ values in terms of free-stream wind speed $\left(U_{\infty}\right)$

The expressions of the variations belonging to the daily average blade tip speed ratios $(\lambda)$ calculated for five wind turbines presented in terms of freestream wind speed $\left(U_{\infty}\right)$ are shown in Figure 7 . It is reported that in order to operate wind turbines at the highest efficiency, their blade tip speed ratios are supposed to be at the average of $\lambda=7.1$ value. On the other hand, the blade tip speed ratio corresponds to an average value of $\lambda=4.5$, under the nominal freestream wind speed value of $U_{\infty}=15 \mathrm{~m} / \mathrm{s}$ in which the wind turbines attain their maximum power generations. Besides, the expressions of the daily average turbine rotor rotational speed $(\Omega)$ values obtained from five wind turbines presented in terms of free-stream wind speed $\left(U_{\infty}\right)$ are demonstrated in Figure 8. It is seen that values belonging to the turbine rotor rotational speed, $\Omega$ generally increase with the increase of free-stream wind speed, $U_{\infty}$. However, in a case when the free-stream wind speed is $U_{\infty}=10 \mathrm{~m} / \mathrm{s}$, it is observed that values belonging to the turbine rotor rotational speed $(\Omega)$ will have the characteristics to be unaltered. Because, when this cited value is exceeded, turbine rotor rotational speed, $\Omega$ generally remains at a constant rotational speed value of approximately $\Omega=16.30 \mathrm{rpm}$. 


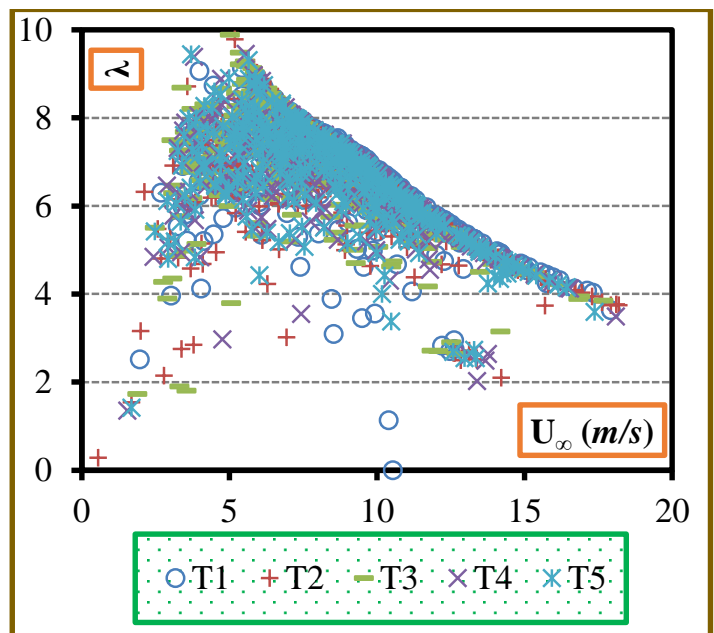

Figure 7. Alteration of daily mean blade tip speed ratio $(\lambda)$ values depending on the freestream wind speed $\left(U_{\infty}\right)$

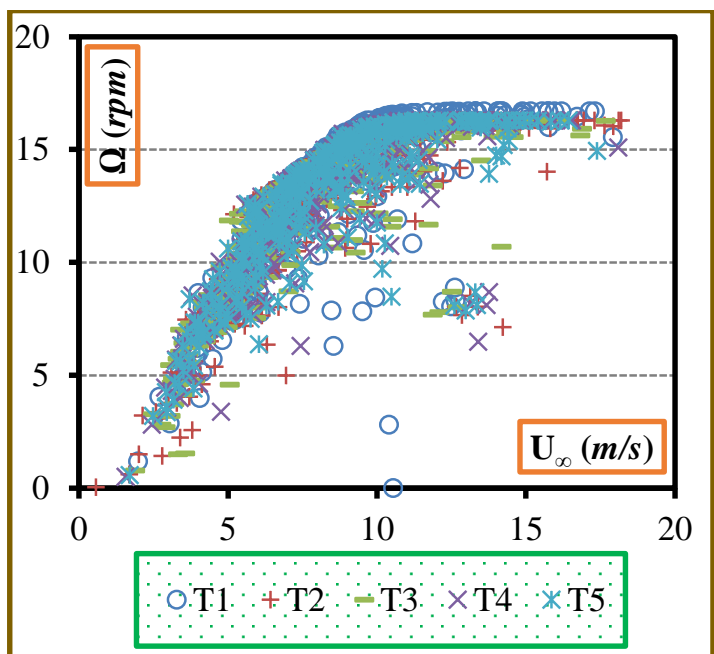

Figure 8. Variation of daily average wind turbine rotor rotational speed $(\Omega)$ values based on the free-stream wind speed $\left(U_{\infty}\right)$

\section{CONCLUSIONS}

In this study, the annual aerodynamic characteristics based on their daily averages and these daily average aerodynamic characteristics determined according to the approaching wind speed of five identical horizontal axis wind turbines of $2 \mathrm{MW}$ rated power operating in an installed wind farm in Hatay/Turkey region have been investigated utilizing aerodynamic and energy analyses tools:

- In the analysis of the WPP, it is conducted that horizontal axis wind turbines with turbine rated power of $P_{r}=2 \mathrm{MW}$ generated annual mean turbine mechanical output power of $P=672.68$ $\mathrm{kW}$, under an annual mean power coefficient of $C_{P}=30.80 \%$, under the annual mean free-stream wind speed of $U_{\infty}=8.49 \mathrm{~m} / \mathrm{s}$, at the annual average wind turbine rotor rotational speed of $\Omega=12.81 \mathrm{rpm}$, at the annual average axial flow induction factor of $a=0.10$ and the thrust coefficient of $C_{T}=0.34$, possesses the annual mean thrust force value of $T=75.18 \mathrm{kN}$, and finally operates at annual average blade tip speed ratio of $\lambda=6.57$. Thus, the efficiency of the five wind turbines in this WPP was also concluded to be high.

- While wind turbine power coefficient reaches the maximum value by exceeding $C_{p}=30 \%$ in the case when the free-stream wind speed values vary in the range between $U_{\infty}=5 \mathrm{~m} / \mathrm{s}$ and $U_{\infty}=10$ $\mathrm{m} / \mathrm{s}$, the average power coefficient value belonging to all wind turbines in this $W P P$ was calculated to be about $C_{p}=18 \%$ under the nominal free-stream wind speed value of $U_{\infty}=15$ $\mathrm{m} / \mathrm{s}$ at which the wind turbines generate maximum power. Based on these conducted outcomes, at the moderate values of free-stream wind speed, higher turbine efficiencies were reported to be obtained.

- The efficiency of a wind turbine is expressed by the value of the power coefficient. Generally the power coefficient is the function of the approaching free-stream wind speed to the rotor disc. However, considering the field operating conditions, the power coefficient value of the turbine is influenced also by the operating conditions. To explain more clearly, while the theoretical possible wind power that is to be obtained by a wind turbine is limited by the Betz limit as provided in Eq. (20); this value of efficiency of $59.3 \%$ is also not possible to be reached by real operating conditions. Namely, when the ideal operating conditions are considered, as demonstrated by the 
manufacturer curve located in the $C_{p}-U_{\infty}$ figure, maximum ideal power in the range of freestream wind speed of $5 \mathrm{~m} / \mathrm{s}<\mathrm{U}_{\infty}<10 \mathrm{~m} / \mathrm{s}$ may only reach $45 \%$. But the real operating conditions, due to the many factors such as the location of the wind turbine, the turbulence influences of the wind, the wind direction, and the unsteady characteristics of the wind stream will certainly cause extra loss of the efficiency. Namely, the operating power coefficient values of the wind turbines will further decrease down to a level of $30 \%$ or slightly more in the operating range of $5 \mathrm{~m} / \mathrm{s}<\mathrm{U}_{\infty}<10 \mathrm{~m} / \mathrm{s}$ of free-stream wind speed. Highest axial flow induction factor $(a)$ obtained in this range of free-stream wind speed as demonstrated in $a-U_{\infty}$ performance curve, indicates the highest capture of the wind energy, by the blades, that will be converted to mechanical energy. This situation is obtained in the above expressed range of freestream wind speed that causes highest wind turbine efficiencies.

- The mean axial flow induction factor $(a)$ and the average thrust coefficient $\left(C_{T}\right)$ values belonging to all wind turbines of this $W P P$ were found to correspond approximately to values of $a=0.10$ and $C_{T}=0.40$, respectively, presented within a free-stream wind speed range varying from $U_{\infty}=5 \mathrm{~m} / \mathrm{s}$ to $U_{\infty}=10 \mathrm{~m} / \mathrm{s}$ where the turbine power coefficient $\left(C_{P}\right)$ coincide to the highest values. However, at the nominal free-stream wind speed value of $15 \mathrm{~m} / \mathrm{s}$ where the wind turbine mechanical output power $(P)$ is maximum, these values were determined approximately at the values of $a=0.05$ and $C_{T}=0.19$, respectively. The parameters of axial flow induction factor, $a$ and thrust coefficient, $C_{T}$ are the measure of the energy convertibility and propulsion effectiveness of the blades. So, it is reported that highest values of $a$ and $C_{T}$ were obtained in parallel at the highest values of $C_{p}$ in Region 2 of wind blowing magnitude.

- The value of maximum thrust force obtained from five wind turbines in WPP reaches approximately $T=144 \mathrm{kN}$ when the value belonging to the free-stream wind speed is approximately, $\mathrm{U}_{\infty}=12.5 \mathrm{~m} / \mathrm{s}$. As in the case of power extraction from the blades, the enhancement of the free-stream wind speed results the increase of thrust force, $T$ up to a certain value of free-stream wind speed. Besides, at the higher values of thrust force, the blades cannot capture the flowing wind due to high wind speed, which result the decrease of blade propulsion. Consequently, the extracted power values will remain at constant values over a certain value of free-stream wind speed.

- In order for the wind turbines of WPP to operate at maximum efficiency, it is conducted that the blade tip speed ratio must be at an average value of $\lambda=7.10$ considering all wind turbines. On the other hand, under the nominal free-stream wind speed value of $U_{\infty}=15 \mathrm{~m} / \mathrm{s}$ at which the wind turbines of the farm reach maximum power generation, the blade tip speed ratio corresponds to an average value of $\lambda=4.50$.

- Wind turbine rotor rotational speed $(\Omega)$ increases with increasing free-stream wind speed $\left(U_{\infty}\right)$, but when the free-stream wind speed is $U_{\infty}=10 \mathrm{~m} / \mathrm{s}$, the turbine rotor rotational speed remains at a constant threshold value of approximately $\Omega=16.30 \mathrm{rpm}$, i.e., the access to the nominal rotor rotational speed $(\Omega)$ value is provided in WPP. The threshold value of the turbines is also explained based on the above physics of wind power extraction phenomenon.

- Although five identical wind turbines were studied in the same wind farm, there is a significant difference in terms of the values of the aerodynamic parameters between them. This is due to the wind farm being situated in the valley containing many hills, crests, and roughness. This topographic condition of the wind farm influences the wind directions and wind characteristics. Ultimately the unsteady wind characteristics result gust effects that negatively influence the performance in some of the wind turbines. Whole studied aerodynamic parameters are linked with each other, as expressed throughout the article. For instance, the power coefficient $\left(C_{p}\right)$ is mainly dependent to the axial flow induction factor $(a)$, since this aerodynamic parameter determines the amount 
of wind energy that is captured by the turbine rotor blades, to be converted to mechanical energy. So, it is expected that the trend of the $a$ $U_{\infty}$ and $C_{p}-U_{\infty}$ curves will be the identical. The study has already shown this situation. Similarly, the analysis of Eq. (27) reveals that the aerodynamic parameters such as the blade tip speed ratio $(\lambda)$ and the rotor rotational speed $(\Omega)$ are also linked with each other. Namely, it is clear that the negative influence occurred on one of both parameters by the topographic conditions will also result the other parameter negatively. To give an example, at $2 \mathrm{~m} / \mathrm{s}$ value of free-stream wind speed, while wind turbine $\mathrm{T} 1$ results a power coefficient value of $C_{p}=22.60 \%$, wind turbine $\mathrm{T} 2$ results a power coefficient value of $C_{p}=10.01 \%$. On the other hand, the value of manufacturer curve or its trend, for $C_{p}$ parameter is identical for whole identical wind turbines, on constant value of free-stream wind speed. So, it is concluded that the discrepancies resulted between the real operating $C_{p}$ values of five wind turbines have been caused by the topographic conditions as well as the wind directions and unsteady wind characteristics.

- Under the utilization of these aerodynamic and energy analyses tools; the values obtained from all wind turbines at the characteristic model curves in terms of aerodynamic context based on the measured values were obtained at values generally lower than the manufacturer characteristic values identified by the wind turbine manufacturer. Thus, it is concluded that many factors including working medium of the wind turbines, cut-in and cut-out functions, the topography, the wear out problems of the turbines, and malfunction periods of them strongly influence the wind turbines to operate at the highest efficiency.

\section{ACKNOWLEDGMENTS}

The authors wish to thank the Office of Scientific Research Projects of Cukurova University for funding this project under the Contract No: FBA2019-11937.

\section{REFERENCES}

1. Kaplan, Y.A., 2015. Overview of Wind Energy in the World and Assessment of Current Wind Energy Policies in Turkey. Renew. Sust. Energ. Rev., 43, 562-568.

2. Waewsak, J., Landry, M., Gagnon, Y., 2015. Offshore Wind Power Potential of the Gulf of Thailand. Renew. Energ., 81, 609-626.

3. Emmanouil, G., Galanis, G., Kalogeri, C., Zodiatis, G., Kallos, G., 2016. 10-Year High Resolution Study of Wind, Sea Waves and Wave Energy Assessment in the Greek Offshore Areas. Renew. Energ., 90, 399-419.

4. Korompili, A., Wu, Q., Zhao, H., 2016. Review of VSC HVDC Connection for Offshore Wind Power Integration. Renew. Sust. Energ. Rev., 59, 1405-1414.

5. Söderholm, P., Pettersson, M., 2011. Offshore Wind Power Policy and Planning in Sweden. Energy Policy, 39(2), 518-525.

6. Kulkarni, P.A., Dhoble, A.S., Padole, P.M., 2018. Deep Neural Network-Based Wind Speed Forecasting and Fatigue Analysis of a Large Composite Wind Turbine Blade. Proc. Inst. Mech. Eng., Part C, 233(8), 2794-2812.

7. Zheng, C.W., Li, C.Y., Pan, J., Liu, M.Y., Xia, L.L., 2016. An Overview of Global Ocean Wind Energy Resource Evaluations. Renew. Sust. Energ. Rev., 53, 1240-1251.

8. Hsu, M.H., 2008. Dynamic Behaviour of Wind Turbine Blades. Proc. Inst. Mech. Eng., Part C, 222(8), 1453-1464.

9. Burton, T., Jenkins, N., Sharpe, D., Bossanyi, E., 2011. Wind Energy Handbook. $2^{\text {nd }}$ ed. John Wiley and Sons, United Kingdom.

10. He, Y.C., Chan, P.W., Li, Q.S., 2013. Wind Characteristics Over Different Terrains. J. Wind Eng. Ind. Aerod., 120, 51-69.

11. Kishinami, K., Taniguchi, H., Suzuki, J., Ibano, H., Kazunou, T., Turuhami, M., 2005. Theoretical and Experimental Study on the Aerodynamic Characteristics of a Horizontal Axis Wind Turbine. Energy, 30, 2089-2100.

12. Sedaghat, A., Assad, M.E.H., Gaith, M., 2014. Aerodynamics Performance of Continuously Variable Speed Horizontal Axis Wind Turbine with Optimal Blades. Energy, 77, 752-759. 
13. Wekesa, D.W., Wang, C., Wei, Y., 2016. Empirical and Numerical Analysis of Small Wind Turbine Aerodynamic Performance at a Plateau Terrain in Kenya. Renew. Energ., 90, 377-385.

14. Ashrafi, Z.N., Ghaderi, M., Sedaghat, A., 2015. Parametric Study on Off-design Aerodynamic Performance of a Horizontal Axis Wind Turbine Blade and Proposed Pitch Control. Energy Convers. Manage., 93, 349-356.

15. Lee, M.H., Shiah, Y.C., Bai, C.J., 2016. Experiments and Numerical Simulations of the Rotor-Blade Performance for a Small-Scale Horizontal Axis Wind Turbine. J. Wind Eng. Ind. Aerod., 149, 17-29.

16. Melo, D.B., Baltazar, J., de Campos, J.A.C.F., 2018. A Numerical Wake Alignment Method for Horizontal Axis Wind Turbines with the Lifting Line Theory. J. Wind Eng. Ind. Aerod., 174, 382-390.

17. Kaya, M.N., Kose, F., Ingham, D., Ma, L., Pourkashanian, M., 2018. Aerodynamic Performance of a Horizontal Axis Wind Turbine with Forward and Backward Swept Blades. J. Wind Eng. Ind. Aerod., 176, 166-173.

18. Pourrajabian, A., Ebrahimi, R., Mirzaei, M., 2014. Applying Micro Scales of Horizontal Axis Wind Turbines for Operation in Low Wind Speed Regions. Energy Convers. Manage., 87, 119-127.

19. Li, Q., Murata, J., Endo, M., Maeda, T., Kamada, Y., 2016. Experimental and Numerical Investigation of the Effect of Turbulent Inflow on a Horizontal Axis Wind Turbine (Part I: Power Performance). Energy, 113, 713-722.

20. Xie, W., Zeng, P., Lei, L., 2017. Wind Tunnel Testing and Improved Blade Element Momentum Method for Umbrella-type Rotor of Horizontal Axis Wind Turbine. Energy, 119, 334-350.

21. Singh, R.K., Ahmed, M.R., Zullah, M.A., Lee, Y.H., 2012. Design of a Low Reynolds Number Airfoil for Small Horizontal Axis Wind Turbines. Renew. Energ., 42, 66-76.

22. Karthikeyan, N., Murugavel, K.K., Kumar, S.A., Rajakumar, S., 2015. Review of Aerodynamic Developments on Small
Horizontal Axis Wind Turbine Blade. Renew. Sust. Energ. Rev., 42, 801-822.

23. Bilgili, M., Tontu, M., Sahin, B., 2021. Aerodynamic Rotor Performance of a 3300-kW Modern Commercial Large-scale Wind Turbine Installed in a Wind Farm. J. Energy Resour. Technol., 143, 031302.

24. Ilhan, A., Bilgili, M., Sahin, B., 2018. Analysis of Aerodynamic Characteristics of $2 \mathrm{MW}$ Horizontal Axis Large Wind Turbine. Wind Struct., 27(3), 187-197.

25. Bilgili, M., Yasar, A., 2017. Performance Evaluation of a Horizontal Axis Wind Turbine in Operation. Int. J. Green Energy, 14(12), 1048-1056.

26. Cooney, C., Byrne, R., Lyons, W., O’Rourke, F., 2017. Performance Characterization of a Commercial-scale Wind Turbine Operating in an Urban Environment. Using Real Data, Energy Sustain Dev, 36, 44-54.

27. Sedaghat, A., Mirhosseini, M., 2012. Aerodynamic Design of a $300 \mathrm{~kW}$ Horizontal Axis Wind Turbine for Province of Semnan. Energy Convers. Manage., 63, 87-94.

28. Taner, T., 2018. Economic Analysis of a Wind Power Plant. A Case Study for the Cappadocia Region, J. Mech. Sci., 32(3), 1379-1389. 
